Arab World English Journal (AWEJ) Volume 12. Number2 June 2021

DOI: https://dx.doi.org/10.24093/awej/vol12no2.31

Pp. $457-468$

\title{
Literary Characters and their Verbal Mimicry through the Prism of Gestalt Analysis
}

\author{
Iryna Morozova \\ Department of English Grammar \\ Odesa Mechnikov National University \\ Odesa, Ukraine \\ Corresponding Author: editor@awej.org \\ Olena Pozharytska \\ Department of English Grammar \\ Odesa Mechnikov National University, \\ Odesa, Ukraine
}

Received: 1/13/2021

Accepted: 6/18/2021

Published: 6/26/2021

\section{Abstract}

The paper represents a fragment of a multi-year project focused on everyday speech interaction and, particularly, on verbal mechanisms of granting speech efficiency and effectiveness. The introductory statement of the research is more precise thespeaker organizes his/her message verbally, the easier it is understood by the listener. Special attention is paid to the methodological approach to verbal identification of literary characters' social strata. The paper also elicits how Gestalt analysis can be successfully applied to different practical linguistic tasks. Hence, the article deals with the advantages of Gestalt, used for unmasking the virtual speaker's social identity and his social status. Besides, a close study of speech situations has revealed some cases when the speaker tries to play a verbal trick on the audience, thus consciously or unconsciously imposing a false image and hiding his/her true identity. The phenomenon of speech imposters, discovered in literary dialogues termed "speech, or verbal mimicry," while the speakers who use such verbal masks are called "mimics." In the presented research, two types of mimicry are distinguished: progressive and regressive speech mimicry. Hence, the characters' speech was analyzed through the prism of his/her actual or imposed social status, which allowed to single out sufficiently reliable syntactic indicators of the speaker's real social profile.

Keywords: Gestalt analysis, literary dialogue, syntactic indicators, verbal/speech mimicry, virtual identity

Cite as: Morozova, I. \& Pozharytska, O. (2021). Literary Characters and their Verbal Mimicry through the Prism of Gestalt Analysis. Arab World English Journal, 12 (2) 457-468.

DOI: https://dx.doi.org/10.24093/awej/vol12no2.31 


\section{Introduction}

The research represents a fragment of a multi-year project focused on everyday speech interaction and, particularly, on the inner verbal mechanisms of granting speech efficiency and effectiveness (Fowler, 1991; Lewis, 1997, 2011; van Son, 2003; Prodi, 2010; Bremner, 2015; Drazic, 2016; Morozova \& Pozharytska, 2016). The term "effectiveness of interpersonal communication" is understood as the speaker's capability to make a specific mental impact on his/her interlocutor (Mc Farlan, 2004).

People speak to get their ideas and thoughts across, to exchange their emotions and aspirations. It is natural that the better the speaker organizes his/her message verbally, the more likely the latter is to be understood by the listener. Consequently, the more productive results can be obtained from a conversation. In the process of our investigation, it has been noticed that the verbal mechanisms, consciously or subconsciously employed by the speaker, are not only shaped up by the speaker's individuality or physical and psychological state but are also influenced by the personality of the listener. In this paper, verbal communication is understood as a two-way street, a joined cooperation between the speaker and the listener, where different factors, like gender, age, social status, and inner psychological relations between the interlocutors are taken into consideration.

\section{Literature Review}

The study of dialogue discourse is concentrated on the internal organization of conversation as a specific role-play, in which its participants take on certain social roles. For example, the Bear from "The Jungle Book" by Kipling (who was teaching a human boy how to survive in the jungle) recommended that his young charge use the following appeal, "We be of one blood, ye and I" as a win-win technique. This "key" to the heart of any inhabitant of the wild is known as "Master words of the jungle." It not only came in handy to Mowgli but also saved his friend Black Panther Bagheera, who had first taken this instruction with significant doubt and only, later on, saw its effectiveness.

The given advice, considered in the light of interpersonal communication, is a humanitarian technique of social adaptation to a particular group or language society. Wodak (2013) stated that a language used in speech and writing is social practice. In fact, "the Master words of the jungle" suggest that one should, consciously or subconsciously, violate certain stereotypes of one's traditional behavior in conversation (conditioned by his/her education, social background, gender, age, nationality, et cetera) to bring one's speech closer to the audience. These considerations allow us to assume that the speaker's social belonging can in most cases be traced through his/her typical individual social speech modifications, i.e., characteristic features lying within the general scope of speech practice but differentiating one social group from another as a shared social habit.

Hall (2011) in his work described the identification of a person as an operation, based on recognition of some common origin or characteristics typical to another person or group. Hence, the concept of identity can be specified as a person's belonging to a particular gender, profession, or age group. 
Studying the phenomenon of identity, the research have quite consciously remained within the limits of "social," or rather "educational" strata of the speaking community singled out on general patterns of their speech. Turning to syntax does not mean underestimating any other language level, like vocabulary or phonetics. Still, it is motivated by the fact of there existing direct correlations between the inner mental structures, defining an individual's mindset, and the surface syntactic structures represented in his/her outer speech (Morozova, 2009, 2010, 2013; Wagner, 2010; Rakhlin, 2011; Morrey, 2012; Pozharytska, 2012).

Our previous investigations have given enough ground to interpret syntactic structures employed by the speaker in the process of communication as a reflection of his/her individual cognitive experience and education (Morozova, 2010, 2013, 2015). In contrast to the straightforward way one's vocabulary might characterize one's inner self. One's syntax should give a more subtle, not too easy to imitate clue about one's social status.

\section{Methods}

The starting point of our research was choosing a suitable language model for studying verbal markers that would permit classifying an individual as a specific social identity, on the one hand and let out his/her efforts to hide it (if necessary), on the other hand.

The current study analyzes virtual literary dialogue taken from modern fiction of different genres written in English. This choice is motivated by the following considerations. First, speaking figuratively, we take literary dialogue as "a still life replica" of a real conversation given by the Author in a definite speech situation. Secondly, this approach seems methodologically valid since it is based on Smith's (1998) "Methodological Diversity" where the Author argues that taken on a sufficiently large scale in terms of the genre and time of its creation, literary dialogue objectively enough manifests typical verbal speech peculiarities of a given society at a certain period.

Syntactic structures as the most abstract lingual code reflect deep cognitive processes, disclosing the speaker's intellectual and psychological potential, and, thus, link up the ways one thinks and speaks. Individual features of personal syntax are not eye- or ear-catching but work on a deeper level of one's perception, involving and reflecting the speaker's personality as a whole. This fact makes syntax practically an ideal field for unmasking the speaker's inner "I," whether it is real or imposed. The microsystem of a literary dialogue discourse, in its turn, objectives all social group norms characteristic of any minor, closed society, representing a group of communicants who can be identified as a specifically organized unity.

The peculiarity of this paper consists in the methodological treatment given to the problem of verbal identification of a literary character's social status. The research is done in the classical traditions of Gestalt analysis and grounds on understanding any linguistic phenomenon as a focused multi-dimensional formation reflected in its Gestalt properties and Gestalt qualities, but still unequal to their total.

The method of Gestalt analysis dates back to the well-known German psychologist Wertheimer (1880-1943), who made a surprising discovery while studying the phenomenon of phantom movement. Any image of a picture of the world, regardless of its simplicity or 
complexity, can be contrasted in human consciousness to an integral phenomenon, which the scientist termed "its Gestalt" (Wertheimer, 1923). There is no English equivalent for the German word "Gestalt." However, it can be understood as "a tangible figure or image" (Duden). Oxford Advanced Learner's Dictionary discloses the term 'gestalt' as "a set of things, such as a person's thoughts or experiences, that is considered as a single system that is different from the individual thoughts, experiences, etc. within it" (OALD). To be more precise, "gestalt" is a specific organization of parts building up an organic entity.

Still, in the thirties, another German philosopher, Ehrenfels, suggested analyzing the entity of any object under study through studying its Gestalt projections taken in different aspects of their existence (1890). However, despite the never-ending interest in Gestalt analysis and its promising perspectives for scientific research, only Lakoff introduced this notion into linguistic analysis in his work "Linguistic Gestalt" (1977).

Today, the Gestalt theory, applied alongside the cognitive approach, has become still more popular in different fields of knowledge, like social psychology, individual psychology, Gestalt-consulting, management, et cetera. In "Phenomenology of Dialogues in Gestalt-theory, Mathematics and Logics" (2009), Chesnokov claims that his forty years' career in applying mathematical analysis methods to linguistics convinced him that all the phenomena of human consciousness can be explained only using Gestalt.

The development of cognitive semantics within linguistics, and, indirectly, the "cognitive revolution" in neuroscience and psychology in general (cf. Neisser, 1997), have renewed the scientific community's interest in Gestalt principles and perspectives for linguistics and reestablished the Gestalt theory as a productive research methodology.

The process of building a Gestalt of a phenomenon is a dynamic operation, which consists in a consecutive consideration of specific features of the subject in question, and foregrounding the so-called "Pragnanz" (pregnancy), or "significance" of its Gestalt in each of the chosen projections (i.e., in the specific angles of vision on the subject under study). Revealing the Pragnanz of a Gestalt presupposes singling out a hierarchical distribution of the dominant property in the Gestalt figure within each of the Gestalt projections.

At the beginning of the 18th century, Berkeley paved the way for the idea of a threedimensional nature of the outer world perception by the human mind (1713). Since then, it has been asserted by philosophers that humans perceive the surrounding world as a threedimensional structure. Purely theoretical initially, this conception has nowadays gained enough objective evidence due to the research done in the field of physics. Grounding upon it, Karch and Randall (2001), and other modern scientists have put forward a theory of a "3D brain," which contributes to explaining of the universe as a three-dimensional space, reflected in human cognition as a three-parameter model of the world. Traditional psychological views on human mentality also support the idea that human takes in the surrounding reality of three-dimensional images (Lundh, 2018). Hence, various investigations of brainwork show that the minimum quantity of projections required for building up a Gestalt of an object under study equals three. It will allow the brain to "complete" the missing parts and form a Gestalt correlating to the phenomenon in question. 


\section{Data Collection Procedure}

In this study, the advantages of using the Gestalt approach will be argued in linguistic investigations and demonstrate its practical application while unmasking a virtual speaker's social identity. Basing upon a thesis that every separate psycho-mental fragment of human consciousness is characterized by simplicity, completeness, and wholeness (Wertheimer, 1997), such fragments, taken, by and large, can be correlated with particular Gestalt formations. To put it differently, our knowledge about an object of reality, its cognition, and hierarchical visualization is contrasted to a certain Gestalt figure, which is, at the level of its mental perception, recognized as a unique entity, clearly outlined against the backdrop of other objects, already familiar to the individual. Thus, a certain speaker's social identity is also built up in his/her audience's minds by taking in his/her speech as a whole, or as a Gestalt.

On the level of mentality, the formation of a specific notion presupposes creating a particular image or figure against the background of other objects. Since essence is manifested in phenomena, a complete Gestalt of the object is conceived through studying its projections. Therefore, the more projections undergo analysis, the more exact and vivid the general image of the construct is. In the process of Gestalt analysis, the 'areal' of the object under study is also taken into consideration. We term 'areal' as a hypothetic textual field where one can see the projected Gestalt object, which, in our case, is literary dialogue.

The authenticity of narration can only be reached by observing the patterns which are realistic and true to life enough for the reader to believe the presented realia. Thus, achieving the effect of immersion, excellent and popular literature is known for, is impossible without its correlation with the real world stereotypes of speech behavior, settled and fixed in the readers' minds. It follows that to be adequately taken in by the reader, a virtual dialogue in fiction has to manifest lingual constructions typical of social and educational backgrounds associated with those of the characters involved in communication.

Interpreting the personages' dialogue and their information exchange, we inevitably face the problem of various ways of information codification in sentences in a given language. It is also quite natural that communicatively loaded syntactic structures, chosen by an individual, are much influenced by his/her social status and education and represent his/her syntax. Warner (1969) singles out three primary social groups in modern society - "the elite," "the middle class," and "the lumpen." Using the suggested terms for socially mapping the personages' speech behavior in the analyzed fiction, we have studied the communicative parties of virtual characters represented in their literary dialogue.

At the first stage of our research, we collected speech samples belonging to different literary characters. Altogether, the corpus of our actual material counts 600 dialogue fragments selected consecutively from modern English-written fiction (about 3,915 average pages). At the next stage of our investigation, all speech parties were classified according to the social model given by Warner (1969). Hence, we conditionally subdivided the literary characters into representatives of "the elite," "the middle class," and "the lumpen." To ensure the validity of the obtained results, we have turned to the methods of mathematical linguistics and calculated the relative mistake, which in all cases did not exceed $8 \%$. 
To "the elite" (from French "élite" - "selection, choice, the distinguished"), we refer refined speakers who have got a higher education and belong to the higher levels of society. The rough, declassed, uneducated representatives are symbolically termed "the lumpen." Between the two given social oppositions, there exists a "sandwich" stratum, termed "the middle class" due to its vertical mobility on the social ladder. We must also stress that the social speech types singled out in the current paper, though originating from Warner's social model, pursue only the goal of verbally identifying the speaker's education level. They have nothing to do with the social stratification of the given language society.

Having chosen syntactic complication of speech utterance (formally corresponding to a sentence) and its lineal organization as the profiles of speech samples analysis, we have worked out three types of Gestalt projections, reflecting syntactic peculiarities of the social groups studied. For this purpose, we used Ehrenfels' circles to outline the areal of syntactically different sentences in the characters' speech parties. The terms - simple sentence, compound, and complex sentence, and complicated sentence - are used here in their traditional understanding in linguistics (Morozova, 2009, 2011; Pozharytska, 2012). By the simple sentence, we understand a sentence containing no more than one primary structure of predication (if any). E.g., I saw a dog. The composite sentence has, besides one primary structure of predication, the secondary predication structure, like a syntactic complex, et cetera. E.g., I saw him cross the street. The compound and complex sentences are built up by two or more primary predication structures. E.g., When I turned the corner, I saw a dog. I turned round the corner, and the dog saw me.

\section{Findings}

In the paper, Gestalt areals are delineated as circles, where three oriented lines running from their centers are conditionally understood as corresponding to the hypothetical maximum use frequency of the speech pattern and taken as $100 \%$ each. The projection types, presented in Figure one, are built up following the principles of "Ehrenfels circles," reflecting the corresponding use frequency areal of the linguistic phenomenon analyzed. The average use frequency of the interrelated linguistic phenomena is identified by dot-marks on each of the given oriented lines. By joining the dots, one gets a Gestalt figure of the communicant's social speech profile in the given projection of vision. Altogether, based on the minimum number of differential criteria required by human consciousness for capturing the essence of a phenomenon (three different angles of sight), Figure one graphically depicts the syntactic speech profiles of different social strata and their correlations perceived by the human mind.

Structurally, within the elite group (a medium grey line), simple sentences (marked as SiSe in Figure one) make up approximately $56.5 \%$, complicated sentences (CoSe in Figure one) with them get a share of $20 \%$, while compound and complex ones (ComSe) count $23.5 \%$ of all speech utterances.

The middle group (a light grey line) is characterised by the average use of simple, complicated, and compound and complex sentences in the following correlation: SiSe $=60 \%$; $\mathrm{CoSe}=12.5 \% ; \mathrm{ComSe}=27.5 \%$. 
The lumpen group (a black line) demonstrates a considerable increase in their preference for simple sentences ( $\mathrm{SiSe}=78 \%$ ). In comparison, compound and complex sentences make up about $13 \%$ and complicated sentences are used $9 \%$ of all cases correspondingly.

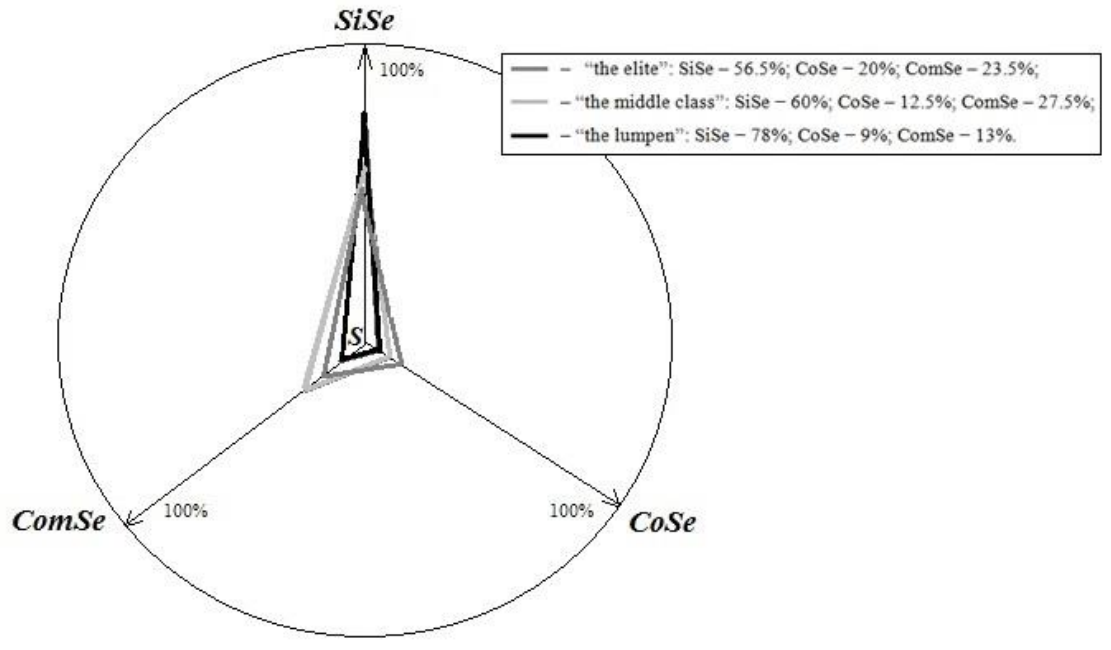

Figure 1. Social and lingual corpora Gestalt projections onto the structural sentence variability

\section{Examples to illustrate Figure one:}

The examples here are given isolated to illustrate the corresponding formal speech patterns, without any reference to the sentence semantics.

The elite:

SiSe: $\quad$ "I should be leaving," he yawned (Brett).

CoSe: $\quad$ "I'll make you very well do it!" I was furious (Gatyss).

ComSe: $\quad$ "See you when I come back on Tuesday" (Christie).

The middle class:

SiSe "I know it," the Cook sighed (Holt).

CoSe "Your late comin' made us worry," Ellie (the maid) looked up at me (Holden).

ComSe I'd wait for you if you came late." Kitty responded to Boss. (Haning)

The "lumpen":

SiSe $\quad$ "So you come?"

"Reckon so," Billy grinned (Fletcher).

$\mathrm{CoSe} \quad$ "Letta go, you brute." $\rightarrow$ (Let me go) (Fletcher).

ComSe "That's jes' wot us be goin' t' tell 'im," Bill said (Gatyss).

\section{Discussion}

It is easy to see that, despite the general Gestalt center shifting to the simple sentences in all projections (see Figure one), the Gestalts of socially different groups of speakers demonstrate 
different types of Gestalt Pragnanz. With the elite, it tends to complicated sentences, while with the lumpen, it remains within simple surface structures. The middle group demonstrates a certain preference for compound and complex sentences. Thus, a conclusion can be drawn from here that more highly educated virtual speakers are characterized by the use of syntactically complicated constructions and a considerable length of sentence elements. It is noteworthy that highly educated personages demonstrate a preference for complicated and not compound and complex constructions. Such complicated build-ups engage more brainwork and mental capacity for a syntactic hide-away of an extra predication structure on a deeper level of syntax. At the same time, compound and complex sentences represent a concatenation of sentence elements and structures of predication.

The main challenge of the current work turned out to be 185 speech samples that were not typical of the representatives of the social groups the literary characters belonged. A close study of the speech situations and dialogue fragments involving the characters that suddenly switched over to speech constructions traditional for other social speech groups revealed a few interesting facts of a conscious/unconscious verbal trick played by such speakers on their listeners. By using syntactic structures that were not frequent with their group, they changed the essential characteristics of their social standing and imposed a wrong image on their audience. This phenomenon that is researched in the literary dialogue we term "speech or verbal mimicry." The term itself falls back to biology and is chosen to indicate a specific way of adjusting and modeling one's speech with the speaker's wish to create a certain image to pursue his/her communicative goal. In biology, the notion of mimicry (from Greek mimikos - imitative) means the protective adaptation of some species of animals and plants, expressed in their similarity with other animals and plants and also with objects of their environment. It has been revealed that in characters' speech, syntactic changes often come along side other alterations in their vocabulary, pronunciation, speech and social behavior, in general.

In most cases, the verbal mimicry is carried out at a conscious level:

"Don't frit. I can be quite decent. I know how good girls speak and look" (Brown).

"The stripper Maddy assures her new acquaintance that she can speak like a well-bred girl and later on tries her best to pass for one. "

The explanation of the fact that conscious mimicry is used so frequently, we see in the speaker's open or unrealized desire to bring his/her message closer to the interlocutor by using the language code typical of the latter. Unaware of his/her personal language code, the speaker, has the idea of the social group the interlocutor is part of, so that kind of social group's speech pattern is imitated to grant a better understanding, on the one hand, and to enhance the speech impact, on the other hand.

Analyzing the "untypical speech utterances" for the type of their verbal adjustment, we have come across two more types of verbal mimicry and now distinguish progressive verbal mimicry (when the speaker tries to imitate a representative of a higher social position or of an overbearing, leading person in this group), and regressive verbal mimicry (when the speaker resorts to speech patterns characteristic of people below his social status or role). 
A universally known example of progressive mimicry is Doolittle's speech party in Shaw's "Pygmalion," where the "lumpen" girl imitates the speech of a lady. A similar type of mimicry is observed in Kendrick's novel "The Curse of Set-Ra-Khatep" where the 12-year-old boy Larry, who is even called "Walking Encyclopedia, " imitates his history teacher's speech:

Larry paused and then said, "My humbled personality was noticed in the library by the two above-mentioned representatives of Egypt" (Kendrick).

In contrast to that speech behavior, in Ray's novel "The Green Island," the twenty-fiveyear-old teacher Ann resorts to regressive mimicry, adjusting her speech to the vernacular of teenage bullies: "You all, listen and pitch-brand it on your...! I shall not only cosh your damned conks but the skin you low and dry..." (Ray)

The boys are taken aback by that kind of treatment from a university graduate, lose their "fighting spirit" and disappear.

The essential situation at hand was as follows: Is it possible to find sufficient syntactic markers of calling the bluff of the mimic in the distorted Gestalt of his/her speech?

\section{Conclusion}

After studying the obtained speech Gestalts of the unmasked mimics, the researcher have come to the following conclusion. We hope to have found sufficiently reliable syntactic indicators of the speaker's real social belonging. These are sentence lineal length and syntactic types of sentence complications. While trying to imitate syntactic speech types of the opposite social group (and it is in most cases an imitated transfer from one of these social layers to the other), both "the elite" and "the lumpen" mimics resort to simplifying or, on the contrary, complicating their utterances by shortening them or increasing their sentence length, correspondingly.

At the same time, a deep insight into their speech Gestalts reveals many interesting regularities. "The elite" mimics imitate "the lumpen" by using the known common vernacular and lineally shortening their utterances. However, in contrast to the true uneducated "lumpen" representatives (who tend to simple sentence structures), educated people start generating lineally short utterances packed with hidden additional predication structures. They reorganize their remarks on the level of their deep sentence structure and make them short but complicated and not simple.

E. g., "Look here, yer lucky dog! Now that I know of your doing all that stuff, I am in business" (Newhouse).

In the example above, a "good" boy imitates the underground style of communication and tries to penetrate the company of street loafers. Nevertheless, he subconsciously uses a gerundial complex, which is not at all typical of the "lumpen" group.

In their turn, "lumpen" speakers, wishing to be taken for upper classes representatives, seek for the ways of complicating their speech parties, and - instead of building up sentences with hidden, secondary predication structures - come up with tagging up additional sentence 
elements, or even extra clauses, chained to the main meaningful part of the utterance on the same level of their usual sentence structure organization.

Hence, we believe that the revealed phenomenon of verbal mimicry is a promising field for future investigation and Gestalt practice. Therefore, Gestalt analysis proves to be a useful approach to practical literary and linguistic studies. Capturing different projections of objects under consideration gives a clue to their conceptual essence, which uncovers their hidden, deep core. It highlights their essential Gestalt organizing qualities, thus, illustrating their perception by the human mind.

About the Author:

Iryna B. Morozova (Doctor of Philology, Full Professor, Odesa Mechnikov National University, Ukraine) was the first in Ukraine to suggest applying the Gestalt theory to linguistic studies. She has authored four monographs, four manuals, altogether 150 papers, among them: Gestalt Analysis as a Means of Language Personality Identification (2013), Handsome is as handsome speaks (2015), Compliments as a specific methodological approach of optimizing the process of teaching foreign languages (2019), etc.

http://orcid.org/0000-0002-1905-7563

Olena Pozharytska $(\mathrm{PhD}$ in Linguistics, Associate Professor, Odesa Mechnikov National University, Ukraine) dedicated a lot of her papers to analysing the literary semantics of "western" novels (e.g., Speaking like a good guy: Speech Carnivalisation Algorithm, 2015). Today, her scientific interests are mostly focused on digital discourse and ludonarrative studies.

http://orcid.org/0000-0003-4820-8129

\section{References}

Altaieva, A. K., Anosova, O. G., Karpukhina, T. P., Pozharytska, O., \& Stepanenko, O. (2013). Movlennyevyj portret holovnoho heroya yak vyrazhennya avtors"koho nachala u tvori [The main character's speech portrait as a reflection of the Author's idea in literature]. Lingvistika i mezhkul'turnaja kommunikacija - innovacionnye podhody i puti razvitija.: monografija [Linguistics and cross-cultural communication - innovative approaches and development patterns: monography]. Kn 1. Odessa: KUPRIENKO, 71-83.

Berkeley, G. (1713). Three dialogues between hylas and philonous. Available at http://www.gutenberg.org/cache/epub/4724/pg4724.txt

Bernstein, A., Hadash, Y., Lichtash, Y., Tanay, G., Shepherd, K., \& Fresco, D.M. (2015). Decentering and related constructs: A critical review and metacognitive process model. Perspectives on Psychological Science, 10(5), 599-617. https://doi.org/10.1177/1745691615594577

Chesnokov, S. V. (2009). Fenomenologija dialogov v geshtal't-teorii, matematike, logike [Phenomenology of dialogues in Gestalt-theory, mathematics, logic]. Moscow: URSS.

Ehrenfels, von Chr. (1890). Über Gestaltqualitäten [On Gestalt-qualities]. Vierteljahrsschrift für wissenschaftliche Philosophie, 14, 249-292.

McFarlan, B. (2004). Drop the pink elephant: 15 Ways to Say What You Mean... and Mean What You Say. London: Capstone. 
Giles, H., \& Powesland, P. F. (1975). Speech style and social evaluation. London: Academic Press (European Monographs in Social Psychology). https://doi.org/10.1002/ejsp.2420100113

Giles, H. \& Ogay, T. (2007). Communication Accomodation Theory. In B. B. Whaley, \& W. Samter, (Eds.), Explaining communication: Contemporary theories and exemplars (pp. 293-310), Mahwah, NJ: Lawrence Erlbaum.

Hall, S. (2011). Fantasy, identity, politics. In E. Carter, J. Donald, \& J. Squires (eds.), Cultural Remix: Theories of Politics and the Popular, 63-69. London: Lawrence and Wishart.

Karch, A., \& Randall, L. (2001). Localized gravity in string theory. Physical review letters, 87 (6). https://doi.org/10.1103/PhysRevLett.87.061601

Lakoff, G. (1977). Linguistic gestalts. Papers from the 13th Regional Meeting Chicago Linguistic Society, 236-287.

Lewis, D. (1996). How to get your message across: A practical guide to power communication. New York: Barnes and Noble.

Lindström, L., \& Mappes, J. (2015). Mimicry. In Oxford Bibliographies: Evolutionary Biology (ed. J. Losos). New York: Oxford University Press.

https://doi.org/10.1093/OBO/9780199941728-0062

Lundh L. G. (2018). Psychological Science within a Three-Dimensional Ontology. Integrative psychological \& behavioral science, 52(1), 52-66. https://doi.org/10.1007/s12124-0179412-8

Morozova I. B. (2009). Paradyhmatychnyj analiz struktury $i$ semantyky elementarnyx komunikatyvnyx odynyc" $u$ svitli heshtal"t-teoriyi $v$ suchasnij anhlijs"kij movi: Monohrafiya [Paradigmatic analysis of the elementary communicative units structure and semantics in the light of the Gestalt-theory in modern English: Monograph]. Odesa: Drukarskij dim.

Morozova, I. B. (2010). Primenenie principov geshtal't-analiza v sintaksicheskih issledovanijah (na materiale anglijskogo jazyka) [Applying the Gestalt-analysis principles to syntactic research (based on the English language corpus study)]. Zapysky z romano-hermans"koyi filolohiyi, vypusk 25. Odes"kyj nacional"nyj universytet im. Mechnykova: fak-t RHF. Odes"kyj nacional"nyj universytet im.Mechnykova: fak-t RHF Odesa: Feniks, 164-171.

Morozova, I. B. (2011). Grammaticheskaja sushhnost' termina "oslozhnennoe predlozhenie" v sovremennom anglijskom jazyke [Grammatical essence of the term "complicated sentence" in modern English]. Visnyk Xarkivs"koho nacional"noho universytetu imeni V.N. Karazina, seriya Romano-hermans"ka filolohiya. Metodyka vykladannya inozemnyx mov, vypusk, 66, 166-173.

Morozova, I. B. (2013). Verbal"nyj konflikt yak osoblyva movlennyeva taktyka v dialozi [Speech conflict as a special speech tactic in dialogue]. Mova: naukovo-teoretychnyj chasopys z movoznavstva, 30-33. Odesa: Astroprynt.

Morozova, I. B. (2015). Rechevaja mimikrija kak kommunikativnaja igra: geshtal't-analiz [Speech mimicry as a communicative game]. Zapysky z romano-hermans"koyi filolohiyi, vypusk 1 (34). Odes"kyj nacional"nyj universytet imeni I.I. Mechnykova: f-t romanohermans"koyi filolohiyi. Odesa: KP OMD, 96-108.

Morozova, I. B., \& Pozharytska, O. (2016). Psiholingvisticheskaja sushhnostt' kommunikativnogo liderstva: geshtal't-analiz [Psycholinguistic nature of communicative leadership: Gestalt-analysis]. Visnyk Xarkivs"koho nacional"noho universytetu imeni V.N. 
Karazina. Seriya “Inozemna filolohiya. Metodyka vykladannya inozemnyx mov”, 84, 1725.

Morrey, L. C. (2012). PAI Assessment. New York: John Wiley.

Neisser, U. A. (1997). Cognitive psychology. New York: Appleton Century-Crofts.

OALD. (n.d.). Oxford Advanced Learner's Dictionary. Available at https://www.oxfordlearnersdictionaries.com/

Perls, F., \& Hefferline, R., \& Goodman, P. (1972). Gestalt therapy. London: Souvenir Press.

Pozharytska, O. (2012). Avtors"kyj koncept pozytyvnosti v xudozhn"omu tvori: filolohichna interpretaciya [The author's concept of the positive in fiction: A linguistic interpretation]. Mova. Naukovo-teoretychnyj chasopys z movoznavstva, №18. Odesa: “Astroprynt”, 5358.

Setti, A. \& Fernandes, S.B. (2019). Knowledge transfer conditioning by the communication processes in the IT/IS Area. In H. Almeida, \& B. Sequeira, (eds.), The role of Knowledge transfer in open innovation (pp. 54-74). Lisbon: Premier Reference Source.

Smith, J. (1998). Methodological Diversity: Advantages and Pitfalls. Language and Social Psychology, 17(3), 32-41.

Warner, W. L. (1969). Social class in America, the evaluation of status, a manual of procedure for the measurement of social status. New York: Harper Collins.

Wertheimer, M. (1923). Laws of organization in perceptual forms. A source book of Gestalt psychology, 71-88. Available at http://psychclassics.yorku.ca/Wertheimer/Forms/forms.htm

Wertheimer, M. (2007). The syllogism and productive thinking. In A source book of Gestalt psychology (pp. 274-282). London: Kegan Paul, Trench, Trubner \& Company.

Wodak, R. (2013). Critical discourse analysis - Challenges and perspectives. In R. Wodak, (ed.), Critical Discourse Analysis (pp. XIX-XXXXiii). 